\title{
Organoleptic And Nutritional Quality Of Wani Fruit (Mangifera Caesia) Sorbet
}

\author{
Ni Putu Eka Trisdayanti, Anak Agung Ketut Alit Pujawan, Ngakan Putu \\ Politeknik Pariwisata Bali, Jln. Dharmawangsa Kampial Nusa Dua \\ *Corresponding Author. E-mail: ekatrisdayanti.ppb@gmail.com
}

\begin{abstract}
Sorbet is one kind of the desserts. Based on the many new variants of sorbet, an idea emerged to make a sorbet with a new variant that has ingredients and benefits that are good for health. In this study focuses on sorbets will be made with the basic ingredients of wani fruit (Mangifera caesia) as its basic ingredient, considering that there has been no research that has processed sorbets with wani fruit (Mangifera caesia) as the base ingredient (Mangifera caesia). In addition, the use of wani fruit (Mangifera caesia) is still limited for fresh consumption, whereas wani fruit (Mangifera caesia) has the potential to be used as a processed product. The author processed the wani fruit (Mangifera caesia) into sorbet, then tested the quality (organoleptic and nutritional). Experiments and organoleptic tests of wani fruit sorbet (Mangifera caesia) were carried out at the Politeknik Pariwisata Bali Bali Tourism Polytechnic campus, and for nutrition tests were carried out at Prodia Food Health Laboratory. The organoleptic results of wani fruit sorbet (Mangifera caesia) are good in terms of taste, aroma, texture, and color, and for the its nutritional content, of wani fruit sorbet (Mangifera caesia) namely consist of $33.1 \%$, of carbohydrates $33.1 \%, 0.475 \%$ of Crude Protein $0.475 \%, 0.330 \%$ of total ash / ash $0.330 \%, 0.5 \%$ of total fat / fat $0.5 \%$, and $65.6 \%$ of water content.
\end{abstract}

Keywords: Sorbet; Mangifera caesia; Organoleptic; Nutrition.

First Received: April 2021 $\quad$ Revised: May 2021 $\quad$ Accepted: May 2021 


\section{Introduction}

Dessert is served last in the food serving hierarchy. According to Nurhidayati (2021), dessert is a dish that has been is served after the main course as a dessert or is commonly referred to as dessert. Dessert is typically sweet and refreshing, but it can also be salty or a combination of the two. Its purpose, as the name implies, is to "wash," or "rinse," the mouth and taste buds to remove any salty, savory, or fishy taste from the main course. Dessert can supplement a person's nutritional needs. Cakes, tarts, and frozen desserts are examples of high-calorie, high-fat desserts. A fruit dessert will ensure an adequate intake of vitamins, minerals, and fiber.

Topan (2020) explains that dessert is also beneficial for body health. These benefits namely are to (1) help control weight, (2) minimize the risk of having a stroke, (3) help lower blood pressure, (4) improve a good mood, (5) increase energy in the body.

Sorbet was is one kind of the desserts. In Indonesia, sorbet is not as popular as ice cream. At first glance, the sorbet dish appears to be the same as ice cream. The sorbet, on the other hand, had a distinct flavor. This ice dish is made entirely of fresh fruit juice and tastes delicious (Wardhani, 2020). Sorbet is a type of ice crystal made from simple syrup with flavors such as juice or fruit juice, fruit puree, wine, liqueur, tea, and herbs (Farrow and Sara, 2006). Sorbet/sherbet is made from water, sugar, and fresh fruit without the use of milk or cream. Sorbet is made solely of fruit and water. Sorbets are known for their fruity flavors that are more palatable than ice cream and emphasize more fruity flavors. Sorbet is widely chosen because it does not contain fat and does not use fresh milk as the main ingredient. In fact, for those who are dieting, some sorbets do not add the sugar at all and are is replaced with dietary sugar (Winneke, 2008).

Currently, sorbet has been produced in many Indonesian restaurants. Many of these restaurants use local ingredients that are easily found in Indonesia, such as basil, ginger, kecombrang, and noni. This of course aims to attract consumer interest as well as promote Indonesian food ingredients. Based on the many new variants of sorbet, an idea emerged to make a sorbet with a new variant that has ingredients and benefits that are good for health. In this study, the sorbet will be made with wani fruit as the base ingredient, considering that there has been no research that has processed sorbet with wani fruit as the base ingredient, and has become one of the most popular local Balinese fruits which have a delicious, sweet, and distinctive flavor (Pradnyawathi)., et al., 2020).

The wani fruit is a kind of mango fruit tree with a pungent smell and sweet-sour taste. Wani has a characteristic thin skin that is pale yellowish to brownish and has patches. The pulp is milky white, fibrous, or barely fibrous, contains a lot of juice, and smells a little foul. Wani is related to kemang, but experts suggest separating it into its type (Wardiyono, 2008). Balinese wani fruit are traded commercially, both traded in traditional markets and supermarkets. According to Rai, Wijana, and Semarajaya (2008), until now, Wani Bali Balinese wani Fruit has not received adequate attention. Utilization of the fruit is still limited for fresh consumption, even though it is still possible to use it as raw material for processed products.

\section{Literature Review}

\subsection{Definition of Sorbet}

Sorbet is an ice crystal made from simple syrup with added flavors of juice or fruit juice, fruit puree, wine, liqueur, tea, or herbs (Farrow and Sara, 2012). In addition, Wahyuni (2012) explained that sorbet is often defined as a dessert made from crushed fruit (puree) with a mixture of water and sucrose, has a shape like ice cream, and has a sweet, refreshing taste (Wahyuni, 2012). According to Arbuckle (1986), 
sorbet consists of sugar, fruit juice, and stabilizers, or you can also add dyes, fruit flavors, and acids. Sorbet has an overrun between $25-24 \%, 25-35 \%$ of sugar content, and a coarse texture.

Sorbet is a dessert made from fruit juice with water and sugar or other sweeteners that are frozen like ice cream but don't contain milk. Sorbet usually has a rougher texture than ice cream. Sorbets can also be made from juice with a mixture of water and sucrose. The advantage of sorbet compared to other frozen dessert products such as ice cream is that it does not contain milk so it is low in fat.

\subsection{Characteristics of Sorbet}

According to Cahyadi et al. (2017), the sorbet has a coarse and easily melted ice crystal structure, so a stabilizer must be added to overcome this problem and make the sorbet texture more homogeneous, smoother, and less easily melted.

The hallmark of an excellent sorbet, according to Farrow and Sara (2012) in their book Ice Cream, is that it has a creamy texture that emerges from the freezing and stirring of a sorbet mixture prepared from top quality and fresh fruit juice or puree. The ingredients in the fabrication however affect the texture and structure of the sorbet significantly by making a sorbet mixture. Sorbet is greatly influenced by the quantity and content of water and sugar. This reduces the freezing temperature when you add alcohol, which means that the sorbet is smoother.

\subsection{Sorbet Nutrition}

Depending on the fundamental ingredients used to manufacture sorbet, the nutritional composition of each serving (one cup) varies. Sorbet can be made from a wide range of fresh fruits or chocolate. Each cup has about 170 to 185 calories on average. When compared to one cup of ice cream (267 calories) or one cup of frozen yogurt (214 calories), this snack has a low-calorie content. Aside from the lower calorie count, the sugar level of this healthy snack is also pretty modest. The average amount of sugar in one dish, which is around 200 grams, is 34 grams. Meanwhile, a serving of ice cream includes 44 grams of sugar, while a serving of yogurt includes 38 grams. Because sorbet is produced entirely of natural ingredients and does not contain any cream or milk, it is naturally sweet and does not require any added sweeteners (Anindyaputri, 2019). Kristiana (2020) adds that fruit sorbet contains a special natural sweetener that makes it taste less sweet.

Sorbet nutrition depends on the basic ingredients, such as sources from Fatsecret Platform API (2007), 1 cup/serving of lime sorbet contains $190 \mathrm{kcal}$ of energy, $0 \mathrm{~g}$ of fat, $1 \mathrm{~g}$ of protein, $46.34 \mathrm{~g}$ of carbohydrates, 0.2 $\mathrm{g}$ of fiber, 39 sugar, $98 \mathrm{~g}$, sodium $16 \mathrm{mg}$, and potassium $200 \mathrm{mg}$. For Strawbery, Mint sorbet contains $130 \mathrm{kcal}$ of energy, 3.53 grams of fat, 3.97 grams of protein, 23.63 grams of carbohydrates, 2.6 grams of fiber, 15.18 grams of sugar, $60 \mathrm{mg}$ of sodium, and $180 \mathrm{mg}$ of potassium (Racbran83, 2011 ) on Fatsecret.co.id.

\subsection{Wani Fruit (Mangifera Caesia)}

The wani fruit is a kind of mango fruit tree with a pungent smell and sweet-sour taste. Wani has a characteristic of thin skin that is pale yellowish to brownish and has patches. The pulp is milky white, fibrous, or barely fibrous, contains a lot of juice, and smells a little foul. Wani is related to kemang, but experts suggest separating it into its type (Wardiyono, 2008). In Agronet (2019), wani is a climacteric fruit, that is, even though the ripening process has been picked, it continues. Sometimes, unripe wani is ripened to speed up the ripening process. Wani which is still thick is also preferred, eaten as a Balinese spice rujak, or eaten directly.

That exist, the type of wani that is easily found in Bali is the Balinese wani. In other areas, the plant is named Kemang (Sundanese and Javanese), Binje (Aceh), Bienglu (Lampung) (Mukherji 1985). The taste of Wani Bali is favored by consumers because it tastes sweet, delicious with a distinctive aroma, and has thick flesh. In 
addition, there are many types with their respective characteristics so that there are various choices for consumers. Until now, Wani Bali Balinese wani fruit has not received adequate attention. Utilization of the fruit is still limited for fresh consumption, even though it is still possible to use it as raw material for processed products. In the fruit trade, Wani Bali has not been taken into account, apart from a lack of promotion, also because of limited production volume due to its very limited population, along with a lack of public interest in developing it. This is very worrying so that preservation and development steps need to be taken immediately.

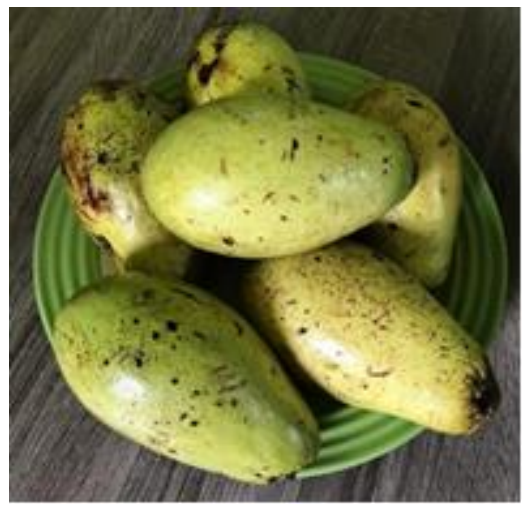

Figure 1. Wani Fruit

Source: Researcher Documentation (2020)

\subsection{Wani Fruit Nutrition}

According to the 2017 Indonesian Food Composition Table, wani fruit has nutritional content, namely 100 grams of fresh wani fruit contains 74 calories, 0.8 grams of protein, 0.3 grams of fat, 17.1 grams of carbohydrates, 3.1 grams of fiber, $66 \mathrm{mg}$ of calcium. , $29 \mathrm{mg}$ of phosphorus, 12 $\mathrm{mg}$ of iron, and $80 \mathrm{mg}$ of vitamin $\mathrm{C}$ (Indonesian Ministry of Health, 2018). According to Indonesia Student (2017), the content of wani fruit itself can form collagen which is the most important protein constituent of all skin, bone, joint, and other supporting tissues. This is because wani fruit contains vitamin $\mathrm{C}$. In addition, wani fruit is also effective for preventing premature aging such as reducing wrinkles. Another content in wani fruit is phosphorus.
Phosphorus is very important for the growth of bones and teeth, especially in reducing the problem of bone loss and functions to keep the kidneys in normal condition. Phosphorus also has an important role in facilitating effective digestion for the body by cleansing the intestines and strengthening the body's stamina. The antioxidant content in wani fruit can maintain the shape and structure of various tissues in the body, such as muscles. Natural antioxidant compounds can ward off free radicals. According to various circles, wani fruit has similarities and also many functions, as with mangoes, which are both high in sugar but low in fat content. Ripe wani fruit provides optimal intake of vitamin $A$ and vitamin $C$ and contains potassium and magnesium which can help with all problems related to muscle cramps, stress, acidosis, and heart problems. Magnesium is a mineral that is needed relatively large by the body. Potassium is used to treat high blood pressure and prevent strokes. The high iron in wani fruit is effective in helping anemia and replacing iron lost through menstruation or pregnancy (Indonesia Student, 2017).

\section{Materials and Methods}

\subsection{Experiment}

This research was conducted by experimenting with the processing of wani fruit into sorbet. The tools used in the processing of wani fruit sorbets are cutting board, knife, hand mixer, blender, stainless steel bowl, balloon whisk, saucepan, measuring jug, digital scale, freezer, stove, plastic container. As for the sorbet processing materials from wani fruit, namely 100 grams of wani fruit, 200 grams of sugar, 300 grams of water, 60 grams of egg white, dry ice. The fruit used is ripe, white, and has a distinctive aroma of wani fruit. This wani fruit sorbet was prepared in the following way:

a. Put sugar and water in a medium-sized saucepan then heat the solution, then stir until the sugar dissolves in the water. 
After that, it is cooled down.

b. Beat the egg whites with a balloon whisk until they are half a meringue

c. After the sugar and boiled water have cooled, mix the flavors such as fruit juice, fruit puree, herbs, or tea in the solution in a bowl

d. Add the meringue mixture to the wani fruit puree mixture.

e. Pour dry ice that has been crushed into small pieces into the wani fruit puree mixture while stirring using a hand mixer. The author uses a hand mixer as a substitute for an Ice Cream Machine in making sorbets so that all levels of society can make sorbets without having to use an Ice Cream Machine.

f. Pour the sorbet mixture into an antifreeze plastic container. Close the container and freeze in the freezer for about 6 hours or until the dough has a texture resembling ice cream.

g. Sorbet is ready to serve.

\section{Results and Discussion}

\subsection{Experiment Result}

After conducting an experiment making sorbets with wani fruit as a base ingredient using ripe wani fruit ingredients with a quantity of 100 grams of wani fruit flesh, $200 \mathrm{ml}$ grams of sugar, $300 \mathrm{ml}$ mineral water, 60 grams of egg whites, with a hardener in the form of crushed dry ice into powder. However, the researchers changed the sorbet-making tool by replacing an ice cream machine with a hand mixer because the sorbet-making process requires cold which tends to be stable and requires constant or continuous stirring so that the sorbet ingredients do not split (not blend). Thus, the researchers also used dry ice to cool the temperature of the sorbet while stirring the sorbet ingredients with a hand mixer so that the researchers got the creamy texture of the sorbet before putting it in the freezer.

After 6 hours in the freezer, the researchers obtained sorbet results that met Joanna Farrow's (2012: 204) sorbet standard,

\subsection{Organoleptic Test}

The processed sorbet from wani fruit was subjected to organoleptic tests (taste, aroma, texture, and color) with a panel of twenty people at the Politeknik Pariwisata Bali (student representatives of the Culinary Management Study Program).

\subsection{Nutrition Test}

In addition to testing the organoleptic quality of the wani fruit sorbet, nutritional quality was also tested to determine the nutritional content of the wani fruit sorbet. The nutrition test for wani fruit sorbet was performed at the Prodia Food Health Laboratory, which is located at Jalan Danau Buyan No.10, Sanur, South Denpasar. Total ash (Muffle Furnace), moisture content (oven), carbohydrate (calculation), total fat (Soxhlet), and protein (Kjedhal) are the parameters tested and the method used.

Following data collection, descriptive qualitative methods were used to analyze the data.

with a creamy texture, not too sweet taste, and not too much wani fruit in the sorbet.

The figure depicts the results of the sorbet experiment using the basic ingredients of wani fruit

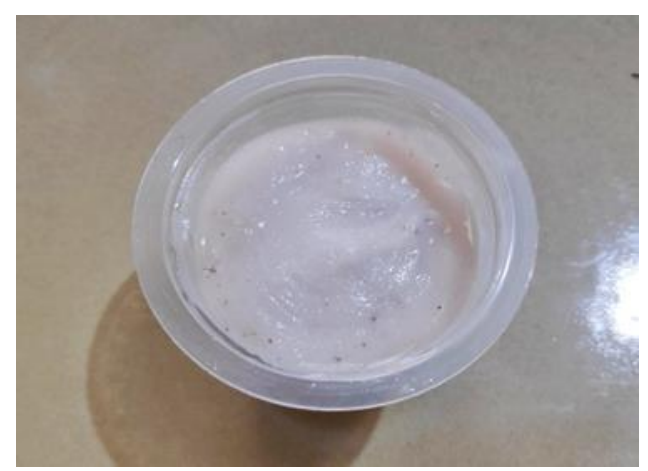

Figure 2. Wani Fruit Sorbet In Plastic Cup Packing

Source: Researcher Documentation (2020)

4.2 Organoleptic Test Result

The organoleptic test results for Wani

Fruit Sorbet are as follows : 
Table 1. Recapitulation of Wani Sorbet Organoleptic Test by 20 Panelists

\begin{tabular}{|c|c|c|c|c|c|}
\hline No & Object & Assessment Aspects & Likert Scale Score & $\begin{array}{l}\text { Number } \\
\text { of } \\
\text { Panelists } \\
\text { who } \\
\text { responded }\end{array}$ & Final Score \\
\hline \multirow[t]{6}{*}{1} & \multirow[t]{5}{*}{ Taste } & Very sweet from the taste of sugar & 5 & 1 & 5 \\
\hline & & Sweet from the taste of sugar & 4 & 5 & 20 \\
\hline & & Sweet enough from the taste of sugar & 3 & 14 & 42 \\
\hline & & Bitter from the taste of wani & 2 & 0 & 0 \\
\hline & & Very bitter from the taste of wani & 1 & 0 & 0 \\
\hline & \multicolumn{2}{|c|}{ Number of Panelists' Answers } & & 20 & 67 \\
\hline \multirow[t]{6}{*}{2} & \multirow[t]{5}{*}{ Aroma } & Very flavorful wani & 5 & 1 & 5 \\
\hline & & flavorful wani & 4 & 14 & 56 \\
\hline & & Flavorful enough wani & 3 & 5 & 15 \\
\hline & & Less flavorful wani & 2 & 0 & 0 \\
\hline & & Not very fragrant & 1 & 0 & 0 \\
\hline & \multicolumn{2}{|c|}{ Number of Panelists' Answers } & & 20 & 76 \\
\hline \multirow[t]{6}{*}{3} & \multirow[t]{5}{*}{ Texture } & Very soft & 5 & 0 & 0 \\
\hline & & Soft & 4 & 10 & 40 \\
\hline & & Soft Enough & 3 & 10 & 30 \\
\hline & & Rough & 2 & 0 & 0 \\
\hline & & Very Rough & 1 & 0 & 0 \\
\hline & \multicolumn{2}{|c|}{ Number of Panelists' Answers } & & 20 & 70 \\
\hline \multirow[t]{6}{*}{4} & \multirow[t]{5}{*}{ Color } & Very Bright & 5 & 1 & 5 \\
\hline & & Bright & 4 & 10 & 40 \\
\hline & & Bright Enough & 3 & 9 & 27 \\
\hline & & Dull & 2 & 0 & 0 \\
\hline & & Very Dull & 1 & 0 & 0 \\
\hline & \multicolumn{3}{|c|}{ Number of Panelists' Answers } & 20 & 72 \\
\hline
\end{tabular}

The data processing of the organoleptic test results was continued in the process of determining the interpretation of the calculation score after the final score on the sorbet wani was obtained. To get the interpretation results, you must first know the highest score $(\mathrm{Y})$ and the lowest number $(\mathrm{X})$. for each assessment object with the following formula:

$\mathrm{Y}=$ Highest Likert Score $\mathrm{x}$ Total Number of Panelists

$\mathrm{X}=$ Lowest Likert Score $\mathrm{x}$ Total Number of Panelists
The object of evaluation is derived from the two formulas. Table 2 shows the formulas for calculating the lowest (X) and highest (Y) scores.:

Table 2. Calculation of the Highest Score (Y) and the Lowest Score (X)

\begin{tabular}{cc}
\hline Lowest Score $(\mathrm{X})$ & Highest Score $(\mathrm{Y})$ \\
\hline $1 \times 20=20$ & $5 \times 20=100$ \\
Source : Research Data $(2020)$
\end{tabular}


For each research item, the highest score (Y) is 100 points and the lowest score $(\mathrm{X})$ is 20 points based on these data. After obtaining the highest (Y) and lowest (X) numbers for each research item, the next step is to determine the interval (distance) of the percent interpretation before learning the result of the interpretation. A solution was used to determine the intervals used in this study, as shown below.:

Interval $=100 \% /$ The number of scores

$$
\begin{aligned}
& \text { used (likert) } \\
= & 100 \% / 5 \\
= & 20 \%
\end{aligned}
$$

As a result, the interval used to determine the interpretation result is $20 \%$. The score interpretation criteria will be used to determine the final results of the organoleptic test research, based on these findings. Table 3 shows the score interpretation criteria that were obtained.:

Table 3. Score Interpretation Criteria Based on The Percentage Obtained

\begin{tabular}{ll}
\hline Percentage $(\%)$ & Score Interpretation Criteria \\
\hline $0 \%-20 \%$ & Very Less \\
$21 \%-40 \%$ & Less \\
$41 \%-60 \%$ & Quite Good \\
$61 \%-80 \%$ & Good \\
$81 \%-100 \%$ & Very Good \\
\hline
\end{tabular}

Source : Research Data (2020)

The next step is to determine the interpretation result of the calculation using the index formula after obtaining the interpretation criteria that will be used as the final research for the organoleptic test. The index formula is calculated by dividing the total score by the highest score and multiplying the result by 100 percent. Table 4 shows the interpretation assessment data processing on variables.:
Table 4. Recapitulation of index values on sorbets made from wani fruit

\begin{tabular}{cccc}
\hline No & Observed Object & $\begin{array}{c}\text { Wani } \\
\text { Index } \\
\text { Value } \\
(\%)\end{array}$ & $\begin{array}{c}\text { Interpretation } \\
\text { Criteria }\end{array}$ \\
\hline 1 & Taste & 67 & Good \\
2 & Aroma & 76 & Good \\
3 & Texture & 70 & Good \\
4 & Color & 72 & Good \\
\multicolumn{5}{c}{ Average Score } & 71.25 & Good \\
Index Value $=$ Total score on each variable / Highest \\
\multicolumn{4}{c}{ Score x 100\% }
\end{tabular}

According to table 4, the organoleptic results of wani fruit sorbets are good in terms of taste, aroma, texture, and color.

\subsection{Nutritional Information of Wani Fruit Sorbet}

Table 5 shows the results of the wani fruit sorbet nutrition test performed at Prodia Food Health Laboratory.

Table 5. Results of Wani Sorbet Nutrition

\begin{tabular}{llcc}
\multicolumn{4}{c}{ (1 Portion) } \\
\hline No & $\begin{array}{c}\text { Nutritional } \\
\text { Content Tested }\end{array}$ & Method & $\begin{array}{c}\text { Analysis } \\
\text { Results } \\
(\%)\end{array}$ \\
\hline 1 & Carbohydrate & Calculation & 33.1 \\
2 & Crude Protein & Kjedhal & 0.475 \\
3 & Total Ash & Muffle & 0.330 \\
& & Furnancce & \\
4 & Total fat & Soxhlet & 0.500 \\
5 & Water Content & Oven & 65.6 \\
\hline \multicolumn{4}{l}{ Resource: Research Result (2020) }
\end{tabular}

In analyzing the data, the authors compared the nutrition of wani fruit sorbets with other fruit-based sorbets, which the authors present in table 6 below. 
Table 6. Nutritional Values Comparison of Wani, Lime, and Strawberry Mint Sorbets

\begin{tabular}{|c|c|c|c|c|c|}
\hline No & Name & $\begin{array}{c}\text { carbohydrate } \\
\text { (gr) }\end{array}$ & $\begin{array}{l}\text { Protein } \\
\text { (gr) }\end{array}$ & Fat (gr) & Source \\
\hline 1 & $\begin{array}{l}\text { Wani } \\
\text { Sorbet }\end{array}$ & 33,1 & 0,48 & 0,50 & $\begin{array}{c}\text { research } \\
\text { ers } \\
(2020)\end{array}$ \\
\hline 2 & $\begin{array}{l}\text { Lime } \\
\text { Sorbet }\end{array}$ & 46,34 & 1 & 0 & $\begin{array}{c}\text { Fatsecret } \\
\text { Platform } \\
\text { API } \\
(2007)\end{array}$ \\
\hline 3 & $\begin{array}{l}\text { Straw } \\
\text { bery } \\
\text { Mint } \\
\text { Sorbet }\end{array}$ & 23,63 & 3,97 & 3,53 & $\begin{array}{c}\text { Racbran } \\
83 \\
(2011) \text { in } \\
\text { Fatsecret }\end{array}$ \\
\hline
\end{tabular}

Source: Processed data (2020)

Table 6 shows that the carbohydrate content of wani sorbet is higher than that of strawberry mint sorbet but lower than that of lime sorbet. The wani sorbet has the lowest protein content when compared to the lime sorbet and the strawberry mint sorbet. The wani fruit sorbet has more fat than the lime sorbet but less than the strawberry mint sorbet. This is consistent with the theory that the nutritional content of sorbets varies depending on the primary ingredients. Nutritional value information can be used as a source of information to select the sorbet to be consumed based on the body's needs.

\section{Conclusions}

Based on the experimental and organoleptic tests of wani fruit sorbet, it is obtained that the sorbet is good in term of taste, color, texture, and aroma. The nutritional content of wani fruit sorbets are $33.1 \%$, of carbohydrate $0.475 \%$ of crude protein $0.330 \%$ of ash $0.330 \%, 0.5 \%$ of fat $0.5 \%$, and $65.6 \%$ of water. For further research, it is advisable to use an ice making machine in the manufacture of sorbets, as the constant stirring process ensures that the ice crystals are as small as possible for a smoother texture.

\section{References}

Agronet. (2019). "Pernah Makan Buah Wani?". [Online]. Tersedia: https://www.agronet.co.id/detail/trave la/feature/4032-Pernah-Makan-Buah-
Wani (21 Maret 2021).

Anindyaputri I. (2019). Dua Resep Sorbet, Camilan Segar Sehat yang Mudah Dibuat.

https://hellosehat.com/hidup-sehat/nu trisi/nutrisi-dan-resep-sorbet/

Arbuckle, W. S. 1986. Ice Cream 4th Edition. Published by Van Nostrand Reinhold Company, New York.

Cahyadi, Wisnu, dkk. (2017). "Penambahan Konsentrasi Bahan Penstabil dan Sukrosa terhadap Karakteristik Sorbet Murbei Hitam" dalam jurnal Pasundan Food Technology Journal. Vol 3 No. 4. Tersedia: https://journal.unpas.ac.id/index.php/f oodtechnology/article/view/649+\&cd $=3 \& \mathrm{hl}=\mathrm{id} \& \mathrm{ct}=\mathrm{clnk} \& \mathrm{gl}=\mathrm{id}$ (23 Maret 2021)

Farrow J, Sara L. (2006). Making Iced Cream and Iced Desserts.ISBN :978-1844762576

Farrow J, Sara L. (2012). Iced Cream. Leichestershire : anness publishing Publisher : Southwater (July 1, 2012)ISBN :978-1780190607

FatSecret Paltform API. (2007). Informasi Gizi Sorbet Rasa Limau. https://www.fatsecret.co.id/kalori-gizi /umum/sorbet-rasa-limau\#: :text=Ter dapat\%20190\%20kalori\%20dalam\% 20Sorbet\%20Rasa\%20Limau\%20(1 $\%$ 20mangkok).

Indonesian Student. (2017). Buah Wani Pengertian, Klasifikasi, Kandungan dan Manfaat https://www.indonesiastudents.com/b uah-wani-pengertian-klarifikasi-kand ungan-dan-manfaat/

Kementerian Kesehatan Republik Indonesia. (2018). Tabel Komposisi Pangan Indonesia 2017. Direktorat Jenderal Kesehatan Masyarakat Direktorat Gizi Masyarakat.

Kristiana, Y., \& Brian, R. (2020). Workshop Kreasi Sorbet Berbahan Buah Dan Sayur Untuk Siswa Sekolah Lentera Harapan (Slh) Curug Tangerang. 
Prosiding Konferensi Nasional Pengabdian Kepada Masyarakat dan Corporate Social Responsibility (PKM-CSR), 3, 956-960.

Mukherji S.K. (1985). Systemic and Ecogeographic Studies of Crop Genepools: Mangifera L. International Board for Plant Genetic Resources (2) : 13-17.

Nurhidayati, Laili. (2021). Teknik Pengolahan Hidangan Kontinental. Jember: Cerdas Ulet Kreatif.

Pradnyawathi, N.L.M. (2020). "PENGEMBANGAN BIBIT BUAH LOKAL UNGGUL WANI BALI TANPA BIJI" dalam jurnal Agroekoteknologi Tropika, 2, (2) : 126-134. Tersedia: https://ojs.unud.ac.id/index.php/jum/a rticle/download/58150/33971/+\&cd= $2 \& \mathrm{hl}=\mathrm{id} \& \mathrm{ct}=\mathrm{c} \operatorname{lnk} \& \mathrm{gl}=\mathrm{id} \quad(23$ Maret 2021)

Racbran83. (2011). Informasi Gizi Strawberry Mint Sorbet. https://www.fatsecret.co.id/member/r acbran83/meals/527884/Strawberry+ Mint+Sorbet

Rai IN., Wijana G. dan Semarajaya,CGA. (2008). Identifikasi Varianilitas Genetik Wani Bali (Mangifera caesia Jack) dengan Analisis Penanda RAPD. J.Hort. 18(2):125-134.

Topan, Tifani. (2020). "5 Manfaat Mengonsumsi Dessert Setelah Makan, Siapa Bilang Bikin Gemuk?" [Online]. Tersedia: https://www.idntimes.com/food/diet/r osma-stifani/5-manfaat-mengonsumsi -dessert-setelah-makan-siapa-bilangbikin-gemuk-c1c2-1 (23 April 2021)

Wahyuni, F. 2012. Kajian Jenis dan Konsentrasi Bahan Penstabil Terhadap Karakteristik Sorbet Sirsak. Artikel Universitas Pasundan, Bandung.

Wardiyono. (2008). Mangifera caesia Jack. http://www.proseanet.org/prohati2/
Whardani, Anita K. (2012). "Sorbet Benar-benar Sajian Segar". [Online]. Tersedia: https://www.tribunnews.com/lifestyle /2012/04/11/sorbet-benar-benar-sajai n-segar. (23 Maret 2021)

Winneke, O. (2008). Sorbet Asam Jawa. http://www.detikfood.com 